\title{
Migration and gout: the Tokelau Island migrant study
}

\author{
I A M PRIOR, T J WELBY, T ØSTBYE, C E SALMOND, Y M STOKES
}

\begin{abstract}
The prevalence and 14 year incidence of clinical gout and its precursors were investigated in the Polynesian population of Tokelauans living in the Pacific basin, non-migrant Tokelauans living in their isolated atoll homeland being compared with migrant Tokelauans living in urban New Zealand. The age standardised prevalence of gout in Tokelauan men in New Zealand was higher than that in non-migrant Tokelauan men, being 21.0 and $19.5 / 1000$ subjects at the beginning of the study and 51.0 and 14.6/1000 at the end of study, respectively. Migrant men in New Zealand aged under 55 had higher mean serum uric acid concentrations than non-migrant men of the same age. The prevalence of gout was low in women in both environments. The age standardised relative risk of developing gout between 1968 and 1982 was 9.0 times higher in the migrant men than in the non-migrant men. Age, serum uric acid concentration, serum cholesterol concentration, and self reported alcohol consumption at entry to the study were the best set of predictors of gout in men.
\end{abstract}

Preventive strategies to change body mass, diet, and patterns of alcohol use need to be developed in this population.

\section{Introduction}

A predisposition to hyperuricaemia and gout has been described in a wide range of Polynesian populations in the Pacific in the past 20 years. In some groups this is linked to other problems, including diabetes, renal failure, hypertension, and obesity. ${ }^{1-5}$ Several preva-

Epidemiology Unit, Wellington Hospital, Wellington, New Zealand

I A M PRIOR, MD, FRCP, director

T J WELBY, BSC, biostatistician

Y M STOKES, BSC, ANZIMLT, biochemist

Department of Community Health, Wellington Clinical School of Medicine, Wellington, New Zealand

T ØSTBYE, MD, MPH, lecturer

CE SALMOND, MSC, senior biostatistician

Correspondence to: Dr I A M Prior, Department of Community Health, Wellington School of Medicine, Wellington Hospital, Private Bag, Newtown, Wellington 2, New Zealand. lence surveys have been carried out, but only one prospective survey has been reported in Polynesians. ${ }^{6}$ This was a study of New Zealand Maoris, which reported a baseline prevalence of gout of $8 \cdot 8 \%$ and a high incidence of $10 \cdot 3 / 100$ subjects over 11 years.

Changes in uric acid concentrations and in the prevalence of gout in response to urbanisation and apparent modernisation have not, however, been uniform in all Polynesians and have varied in different studies. ${ }^{4-9}$ An earlier study comparing Hawaiians with New Zealand Maoris suggested that they had similar patterns of obesity and hypertension but that the Hawaiians had low serum uric acid concentrations and no gout. ${ }^{10}$ More recent studies of Micronesians in Nauru have shown high rates of hyperuricaemia (64\%) and gout $(6.9 \%)$ in men. ${ }^{9}$ This is thought to be related to their extraordinary affluence and lifestyle based on their prosperous phosphate economy. Also in the Pacific a recent study from Japan suggested that urbanisation and change to a diet with a higher intake of animal protein and fat was causing an increase in hyperuricaemia and gout."

The Tokelau Island migrant study, established in 1967 as a multidisciplinary investigation of migration and health in Tokelauans, provided an opportunity to examine the specific effect of urbanisation on the prevalence and incidence of gout in a genetically homogeneous group. ${ }^{12}$ The unique feature of the study was the documentation of the health of migrants from isolated Tokelau to urban New Zealand both before and after migration. ${ }^{13} 14$

Tokelau consists of three small isolated atolls (Fakaofo, Nukunonu, and Atafu) $3200 \mathrm{~km}$ north of New Zealand. Since the mid1960 s a large proportion of its population has migrated to New Zealand so that by 1982 nearly two thirds of all Tokelauans ( 2800 out of 4360) were living in New Zealand. Life in Tokelau follows a traditional pattern with a subsistence economy dependent on fishing and harvesting of copra, which is exported to Western Samoa. In recent years more salaried positions have been established with the development of the Tokelau Public Service and stores have become better equipped and able to offer a wider range of foods, including rice, flour, and sugar. The staple diet consists of coconuts, which give about $54 \%$ of energy, fish, and breadfruit supplemented by rice, flour, and sugar. ${ }^{1516}$

The diet of islanders who migrate to New Zealand undergoes a major change, with an increase in the proportion of meat, carbohydrates, and dairy products including milk and cream. The overall energy intake is higher in New Zealand. ${ }^{16}$ In Tokelau in the mid1970 s the total fat intake, which comes largely from coconut, accounted for $48 \%$ of energy and saturated fat yielded $43 \%$ of 
energy; in New Zealand total fat intake accounted for $41 \%$ of energy, with saturated fat yielding $21 \%$. $^{16}$

This report describes the changing prevalence and incidence of gout among Tokelauans in Tokelau and New Zealand and is based on repeated surveys carried out from 1968 to 1982.

\section{Subjects and methods}

In Tokelau the baseline population for this study comprised 933 adults aged 15 and over seen in either 1968 in the atoll of Fakaofo or in 1971 in the atolls of Atafu and Nukunonu. In these two surveys short medical examinations that did not include a diagnosis or history of gout were conducted in the remaining atoll(s). A further 156 adults were seen but were excluded from the baseline population: 142 were given short examinations in 1968 and then migrated to New Zealand or elsewhere before 1971 , and 14 were either missed or received a short examination in 1971. Re-examinations in Tokelau took place in 1976 and again in 1982; 802 and 809 people were seen, respectively. The overall refusal rate was $4 \%$. Pregnant women were excluded from the analyses in all rounds.

A register of Tokelauans in New Zealand was established and maintained throughout the study. Examinations of all Tokelauans in New Zealand were carried out in 1972-4, 1975-7, and 1980-1;1048, 1174, and 1366 adults, respectively, were examined. The overall refusal rate was $2 \cdot 8 \%$. The combination of the baseline surveys in Tokelau and the initial survey in New Zealand is referred to as round I. Round II and round III are the combinations of the surveys at the middle and the end of the period, respectively. After round I 860 eligible subjects entered the study, mostly by attaining 15 years of age.

Gout was diagnosed on the basis of a history of at least two episodes of classical podagra with redness and swelling of a first metatarsophalangeal joint ${ }^{17}$ Serum uric acid concentration was not used in the classification as its effect was sought as an independent risk factor.

Cross sectional survey data were used to calculate the prevalence of gout per 1000 migrants and non-migrants, who were classified as such on the basis of their place of residence at the time of an examination. Adults were included in the incidence study if they were examined in two or more rounds and were gout free at entry. For subjects who developed gout the number of person years at risk of developing gout was calculated by assuming that the time of onset was the midpoint between the rounds during which gout was known to have developed. Migrants who later returned to Tokelau were excluded from the study at the time of return.

Tests for linear trend of the prevalence of gout over time were performed with the method of Mantel. ${ }^{18}$ Age standardised incidences (new cases of gout $/ 10000$ person years at risk) are reported, as well as the relative risk of developing gout between the two environments. A subject's years at risk were apportioned to the age groups that the subject passed through during the study in order to standardise the incidences for age. In calculations of both prevalence and incidence the direct method of age standardisation was used. ${ }^{19}$ Reference populations were constructed by pooling total numbers seen (in the prevalence study) or person years at risk (in the incidence study). (Relative risk was estimated by the Mantel-Haenszel method. ${ }^{20}$ )

Serum samples were separated and frozen within eight hours of venepuncture. Serum uric acid concentrations were later measured by a Technicon autoanalyser. ${ }^{21}$ Satisfactory quality control was maintained throughout with commercially prepared serum samples with high and low controls. Standard methods for recording systolic and fourth phase diastolic blood pressures with a random zero sphygmomanometer have been reported elsewhere. ${ }^{13}$ Blood samples were also collected and assayed for serum total cholesterol and triglyceride concentrations as reported previously. ${ }^{22}$

Analysis of covariance was used to determine cross sectional differences in serum uric acid concentrations between the migrants in New Zealand and the non-migrants in Tokelau, controlling for sex, age, and body mass $\left(1000 \times\right.$ weight in $\left.\mathrm{kg} /(\text { height in } \mathrm{cm})^{2}\right)$. Round I data were not included in this analysis because of a known laboratory bias in assays of Tokelau samples collected in 1971.

The relation between a subject's health state at entry to the study and the subsequent development of gout was investigated. Those developing gout were compared with the rest of the population for their mean body mass index, weight $(\mathrm{kg})$, height $(\mathrm{cm})$, upper arm circumference $(\mathrm{cm})$, subscapular and triceps skinfold thicknesses ( $\mathrm{mm}$ ), systolic and fourth phase diastolic blood pressures $(\mathrm{mm} \mathrm{Hg})$, and serum cholesterol, triglyceride, and uric acid concentrations ( $\mathrm{mmol} / \mathrm{l})$ at entry. A composite measure of upper arm muscle circumference was also included; this had been associated with the incidence of gout in a previous study. ${ }^{6}$ The analysis of incidence was confined to men as there were too few cases among women for a useful comparison. The difference between the age distributions of people developing gout and those not was controlled for by analysis of covariance.

Univariate and forward stepwise multivariate logistic regression analyses were also carried out ${ }^{23}$ Included as candidate predictors of disease state were the independent variables listed above together with a dummy variable indicating whether a person had spent any time in New Zealand during the study $(0=$ no exposure, $1=$ exposure). Also included was a second dummy variable indicating the self reported current alcohol consumption at entry $(0=$ no, $1=$ yes $)$. Predictors were included in the "best" model if they were significant at the $5 \%$ level after the effects of other variables already included had been controlled for. Multiple logistic regression permits the estimation of relative risks adjusted for the other independent variables. Multicollinearity was not a problem in selecting the best predictors.

Significance was assessed at the nominal $5 \%$ level for all comparisons made. Calculations were facilitated by the Statistical Analysis System. ${ }^{24}$

\section{Results}

\section{PREVALENCE}

The place, sex, and age specific prevalences of gout in rounds I and III suggested that gout was more common in migrants than non-migrants and men than women, occurred in younger migrants, and became more common as the migrants stayed longer in New Zealand (table I). This was confirmed by statistical analysis of the age standardised prevalences (table II).

Over the three examination rounds the age standardised prevalence of gout was higher in the migrant than the non-migrant men but significantly so only at round III, when the estimated relative risk of gout of 3.7 was significantly higher among migrant $\operatorname{men}\left(\chi^{2}(1)=8.67 ; p<0.01\right)$. A test for trend in prevalence over the three rounds showed a significant increasing linear trend of prevalence among migrant $\operatorname{men}\left(\chi^{2}(1)=8.51 ; p<0.01\right)$ but not among non-migrant men $\left(\chi^{2}(1)=0.39 ; p=0.53\right)$. The age standardised prevalence of gout in the women was not analysed because of the few cases.

In men and women migrants and non-migrants at round II mean serum uric acid concentrations increased with age. In controlling for age in cross sectional comparisons of the mean concentrations it was necessary to split

TABLE I-Prevalence of gout among migrant and non-migrant Tokelauan men and women at beginning and end of study

\begin{tabular}{|c|c|c|c|c|c|c|c|c|c|c|c|c|c|c|c|c|}
\hline \multirow[b]{4}{*}{$\begin{array}{c}\text { Age } \\
\text { group } \\
\text { (years) }\end{array}$} & \multicolumn{8}{|c|}{ Round I } & \multicolumn{8}{|c|}{ Round III } \\
\hline & \multicolumn{4}{|c|}{ Men } & \multicolumn{4}{|c|}{ Women ${ }^{\star}$} & \multicolumn{4}{|c|}{ Men } & \multicolumn{4}{|c|}{ Women ${ }^{\star}$} \\
\hline & \multicolumn{2}{|c|}{ Migrant } & \multicolumn{2}{|c|}{ Non-migrant } & \multicolumn{2}{|c|}{ Migrant } & \multicolumn{2}{|c|}{ Non-migrant } & \multicolumn{2}{|c|}{ Migrant } & \multicolumn{2}{|c|}{ Non-migrant } & \multicolumn{2}{|c|}{ Migrant } & \multicolumn{2}{|c|}{ Non-migrant } \\
\hline & $\begin{array}{l}\text { No of } \\
\text { subjects } \\
\text { with gout }\end{array}$ & $\begin{array}{c}\text { No } \\
\text { examined }\end{array}$ & $\begin{array}{c}\begin{array}{c}\text { No of } \\
\text { subjects } \\
\text { with gout }\end{array} \\
\text { we }\end{array}$ & $\begin{array}{c}\text { No } \\
\text { examined }\end{array}$ & $\begin{array}{l}\text { No of } \\
\text { subjects } \\
\text { with gout }\end{array}$ & $\begin{array}{c}\text { No } \\
\text { examined }\end{array}$ & $\begin{array}{c}\begin{array}{c}\text { No of } \\
\text { subjects } \\
\text { with gout }\end{array} \\
\end{array}$ & $\begin{array}{c}\text { No } \\
\text { examined }\end{array}$ & $\begin{array}{c}\begin{array}{c}\text { No of } \\
\text { subjects } \\
\text { with gout }\end{array} \\
\end{array}$ & $\begin{array}{c}\text { No } \\
\text { examined }\end{array}$ & $\begin{array}{c}\begin{array}{c}\text { No of } \\
\text { subjects } \\
\text { with gout }\end{array} \\
\end{array}$ & $\begin{array}{c}\text { No } \\
\text { examined }\end{array}$ & $\begin{array}{l}\text { No of } \\
\text { subjects } \\
\text { with gout }\end{array}$ & $\begin{array}{c}\text { No } \\
\text { examined }\end{array}$ & $\begin{array}{l}\text { No of } \\
\text { subjects } \\
\text { with gout } e\end{array}$ & $\begin{array}{c}\text { No } \\
\text { examined }\end{array}$ \\
\hline $15-19$ & & 91 & & 89 & & 78 & & 101 & & 113 & & 61 & & 107 & & 45 \\
\hline $20-24$ & & 94 & & 25 & & 80 & & 54 & & 121 & & 58 & & 82 & & 50 \\
\hline $25-34$ & & 160 & & 59 & & 118 & & 72 & 1 & 181 & & 68 & 1 & 162 & & 89 \\
\hline $35-44$ & 3 & 89 & & 69 & & $\begin{array}{r}118 \\
62\end{array}$ & & 88 & 15 & $\begin{array}{l}101 \\
133\end{array}$ & & 40 & 2 & 115 & & 64 \\
\hline $45-54$ & 1 & 57 & 3 & 68 & & 45 & & $\begin{array}{l}60 \\
66\end{array}$ & 8 & 82 & 2 & 46 & 1 & 74 & & 63 \\
\hline $55-64$ & 3 & 42 & 2 & 39 & & 33 & & 52 & 6 & 56 & 1 & 45 & & 35 & & \\
\hline $\begin{array}{l}35-64 \\
65-74\end{array}$ & 2 & ${ }_{25}^{42}$ & 2 & 23 & & 24 & & 28 & 2 & 20 & 1 & 32 & & 23 & & 27 \\
\hline$\geqslant 75$ & & & 2 & 26 & & & & $\begin{array}{l}28 \\
44\end{array}$ & 1 & 4 & 2 & 22 & & 10 & & 35 \\
\hline Total & 10 & 558 & 9 & 398 & & 440 & & 505 & 33 & 710 & 7 & 372 & 4 & 608 & & 420 \\
\hline
\end{tabular}

* Excluding pregnant women at examination. 
TABLE II-Age standardised prevalence of gout in Tokelauan migrant and non-migrant men

\begin{tabular}{|c|c|c|c|c|c|}
\hline \multirow[b]{2}{*}{ Round } & \multicolumn{2}{|c|}{ Subjects with gout/total } & \multicolumn{2}{|c|}{$\begin{array}{l}\text { Prevalence of } \\
\text { gout } / 1000 \text { subjects }\end{array}$} & \multirow{2}{*}{$\begin{array}{l}\text { Relative risk }{ }^{\star}(95 \% \\
\text { confidence intervals) }\end{array}$} \\
\hline & Migrants & Non-migrants & Migrants & Non-migrants & \\
\hline I & $10 / 558^{\circ}$ & 9/398 & $21 \cdot 0$ & $19 \cdot 5$ & $1.1(0.4$ to 2.7$)$ \\
\hline II & $18 / 616$ & $7 / 339$ & $35 \cdot 1$ & $15 \cdot 0$ & $2.8(0.9$ to 9.1$)$ \\
\hline III & $33 / 710$ & $7 / 372$ & $51 \cdot 0$ & $14 \cdot 6$ & $3.7(1.6$ to 8.9$)$ \\
\hline
\end{tabular}

* Migrant $v$ non-migrant men.

the men into two age groups to satisfy the statistical assumption that the regressions with age for migrants and non-migrants were parallel. Thus in round III migrant men younger than 55 had an adjusted mean serum uric acid concentration that was $0.017 \mathrm{mmol} / \mathrm{l}$ above that of the non-migrants of the same age $(p=0.002)$. Older men migrants ( 55 and over) had an average concentration $0.028 \mathrm{mmol} / 1$ lower than that of their non-migrant compatriots $(p=0.04)$. A similar pattern was seen for round II, although this was not significant $(p=0.58)$. Non-migrant women in round II had a significantly higher mean concentration than migrants by $0.01 \mathrm{mmol} / \mathrm{l}(\mathrm{p}=0.04)$, but by round III the difference in women was not significant $(p=0 \cdot 27)$. Table III shows these results. differences were found. The amount of variability about the means was generally larger in the people developing gout than in the remainder of the population.

TABLE V-Age standardised risk factors at recruitment for gout in men. (Values are means $(S D)$ )

\begin{tabular}{|c|c|c|c|}
\hline Risk factor at recruitment & $\begin{array}{c}\text { Men not } \\
\text { developing } \\
\text { gout }(\mathbf{n}=875)\end{array}$ & $\begin{array}{c}\text { Men } \\
\text { developing } \\
\text { gout }(n=38)\end{array}$ & $\begin{array}{l}95 \% \text { Confidence } \\
\text { interval for Aean } \\
\text { difference, } \\
\text { controlling } \\
\text { for age }\end{array}$ \\
\hline $\begin{array}{l}\text { Age (years) } \\
\text { Body mass index }\left(\mathrm{kg} / \mathrm{cm}^{2}\right) \\
\text { Weight }(\mathrm{kg}) \\
\text { Height }(\mathrm{cm}) \\
\text { Arm circumference }(\mathrm{cm}) \\
\text { Arm muscle circumference }(\mathrm{cm}) \\
\text { Subscapular skinfold thickness }(\mathrm{mm}) \\
\text { Triceps skinfold thickness }(\mathrm{mm}) \\
\text { Systolic blood pressure }(\mathrm{mm} \mathrm{Hg}) \\
\text { Diastolic blood pressure }(\mathrm{mm} \mathrm{Hg}) \\
\text { Cholesterol }(\mathrm{mmol} / \mathrm{l}) \\
\text { Triglyceride }(\mathrm{mmol} / \mathrm{l}) \\
\text { Serum uric acid }(\mathrm{mmol} / \mathrm{l})\end{array}$ & $\begin{aligned} 32 \cdot 50(15 \cdot 54) \\
2 \cdot 60(0 \cdot 39) \\
74 \cdot 53(13 \cdot 07) \\
169 \cdot 20(5 \cdot 82) \\
32 \cdot 68(3 \cdot 77) \\
28 \cdot 71(2 \cdot 89) \\
12 \cdot 68(6 \cdot 25) \\
12 \cdot 56(5 \cdot 45) \\
122 \cdot 90(16 \cdot 77) \\
73 \cdot 47(12 \cdot 40) \\
5 \cdot 14(0 \cdot 98) \\
0.95(0 \cdot 73) \\
0.39(0.07)\end{aligned}$ & $\begin{array}{r}40.94(14.01) \\
2.94(0.44) \\
85.28(15.95) \\
169.92(5.57) \\
35.61(3.78) \\
30.17(2.25) \\
17.53(7.55) \\
17.29(8.71) \\
134.84(17.72) \\
83.75(13.24) \\
5.68(1.11) \\
1.49(1.10) \\
0.47(0.08)\end{array}$ & $\begin{array}{r}0.16 \text { to } 0.40 \\
4.83 \text { to } 13.23 \\
-0.95 \text { to } 2.84 \\
1.11 \text { to } 3.45 \\
0.19 \text { to } 2.01 \\
1.53 \text { to } 5.34 \\
2.07 \text { to } 5.58 \\
3.16 \text { to } 13.17 \\
4.53 \text { to } 12.35 \\
0.03 \text { to } 0.64 \\
0.25 \text { to } 0.75 \\
0.07 \text { to } 0.12\end{array}$ \\
\hline
\end{tabular}

TABLE III-Mean (SE) serum uric acid concentrations (mmol/l) in Tokelauan migrant and non-migrant men and women at each examination

\begin{tabular}{|c|c|c|c|c|c|c|c|}
\hline \multirow[b]{2}{*}{ Round } & \multicolumn{2}{|c|}{ No of subjects $\$$} & \multicolumn{2}{|c|}{ Unadjusted concentration } & \multicolumn{2}{|c|}{ Adjusted concentration ${ }^{\star}$} & \multirow[b]{2}{*}{$\begin{array}{l}95 \% \text { Confidence interval } \\
\text { for difference }\end{array}$} \\
\hline & Migrant & Non-migrant & Migrant & Non-migrant & $\begin{array}{c}\text { Migrant } \\
\text { Mean }\end{array}$ & $\begin{array}{c}\text { Non-migrant } \\
\text { Mean }\end{array}$ & \\
\hline & & & & Men & & & \\
\hline I & 551 & 388 & $0.414(0.003)$ & $t$ & $t$ & $t$ & \\
\hline II $\left\{\begin{array}{l}<55 \text { years } \\
\geqslant 55 \text { years }\end{array}\right.$ & $\begin{array}{r}555 \\
55\end{array}$ & $\begin{array}{r}250 \\
76\end{array}$ & $\begin{array}{l}0.419(0.003) \\
0.409(0.009)\end{array}$ & $\begin{array}{l}0.406(0.004) \\
0.427(0.010)\end{array}$ & $\begin{array}{l}0.424 \\
0.403\end{array}$ & $\begin{array}{l}0.421 \\
0.417\end{array}$ & $\begin{array}{l}-0.007 \text { to } 0.013 \\
-0.040 \text { to } 0.013\end{array}$ \\
\hline III $\left\{\begin{array}{l}<55 \text { years } \\
\geqslant 55 \text { years }\end{array}\right.$ & $\begin{array}{r}575 \\
65\end{array}$ & $\begin{array}{r}265 \\
75\end{array}$ & $\begin{array}{l}0.413(0.003) \\
0.391(0.010)\end{array}$ & $\begin{array}{l}0.388(0.004) \\
0.418(0.009)\end{array}$ & $\begin{array}{l}0.417 \\
0.394\end{array}$ & $\begin{array}{l}0.400 \\
0.422\end{array}$ & $\begin{array}{l}0.006 \text { to } 0.028 \\
0.055 \text { to }-0.001\end{array}$ \\
\hline $\begin{array}{l}\text { I } \\
\text { II } \\
\text { III }\end{array}$ & $\begin{array}{l}426 \\
485 \\
527\end{array}$ & $\begin{array}{l}488 \\
414 \\
346\end{array}$ & $\begin{array}{l}0.347(0.004) \\
0.340(0.003) \\
0.340(0.003)\end{array}$ & $\begin{array}{c}\text { Woment } \\
t \\
0.351(0.004) \\
0.333(0.004)\end{array}$ & $\begin{array}{c}t \\
0.339 \\
0.336\end{array}$ & $\begin{array}{c}t \\
0 \cdot 348 \\
0 \cdot 331\end{array}$ & $\begin{array}{l}-0.018 \text { to }-0.0003 \\
-0.004 \text { to } 0.014\end{array}$ \\
\hline
\end{tabular}

* Covariance adjusted to a body mass index of $2 \cdot 9 \mathrm{~kg} / \mathrm{cm}^{2}$ and age either 35 or 60 in men and 35 for women.

† Results not available.

$\ddagger$ Excluding women pregnant at examinations.

§Subjects with available sera.

\section{INCIDENCE}

Table IV shows the number of new cases of gout occurring in the migrants and non-migrants between 1968 and 1982 . Of the 1705 people included in the incidence study, 46 developed gout, of whom eight were women. Four non-migrant men and 30 migrant men aged 35 and over developed gout, 17 of the migrants being 35-44. Three non-migrant women and five migrant women, all aged over 35, developed gout. Age standardised incidences were $90 \cdot 7$ and $11 \cdot 2 / 10000$ person years at risk in migrant and non-migrant men, respectively. The age standardised relative risk of developing gout for migrant versus non-migrant men was 9.0 $\left(\chi^{2}(1)=20.27 ; p<0.0001\right)$. Migrant women did not show a higher risk of gout than non-migrant women $\left(\chi^{2}(1)=2 \cdot 04 ; p=0 \cdot 15\right)$.

On average people who developed gout were 8.4 years older at entry than those who remained gout free (table V). After controlling for age differences at entry, the means of all variables presented in this table were significantly higher among the subjects with gout, except for height, for which no

TABLE IV-Age adjusted incidence of gout

\begin{tabular}{lccccc}
\hline & \multicolumn{2}{c}{ Men } & & \multicolumn{2}{c}{ Women } \\
\cline { 2 - 3 } \cline { 5 - 6 } & Migrants & Non-migrants & & Migrants & Non-migrants \\
\hline $\begin{array}{l}\text { No of new cases } \\
\begin{array}{l}\text { No of person years at risk } \\
\text { Incidence (per 10000 person } \\
\text { years at risk) }\end{array}\end{array}$ & 4199 & 3182 & & 5 & 3 \\
$\begin{array}{l}\text { Relative risk for migrants } v \\
\text { non-migrants (95\% confidence } \\
\text { interval) }\end{array}$ & 90.7 & 11.2 & & 18.8 & 7862 \\
\hline
\end{tabular}

Table VI shows the univariate and multivariate logistic regression coefficients for men. In the univariate analysis all the confounding variables

TABLE VI-Maximum likelihood estimates of regression coefficients for logistic models relating risk factors at entry to 14 year incidence of gout

\begin{tabular}{|c|c|c|c|c|}
\hline & \multicolumn{2}{|c|}{ Univariate regressions } & \multicolumn{2}{|c|}{ Multivariate regression ${ }^{\star}$} \\
\hline & Coefficient & $\begin{array}{l}95 \% \text { Confidence } \\
\text { interval }\end{array}$ & Coefficient & $\begin{array}{l}\text { 95\% Confidence } \\
\text { interval }\end{array}$ \\
\hline Intercept & & & $-14 \cdot 26$ & $-17 \cdot 72$ to $-10 \cdot 79$ \\
\hline New Zealand exposure & 1.34 & 0.29 to 2.39 & & \\
\hline Age (years) & 0.03 & -0.01 to 0.05 & 0.05 & 0.02 to \\
\hline Body mass index $\left(\mathrm{kg} / \mathrm{cm}^{2}\right)$ & $1 \cdot 77$ & 1.08 to 2.47 & & \\
\hline Weight (kg) & 0.05 & 0.03 to 0.07 & & \\
\hline Height $(\mathrm{cm})$ & 0.02 & -0.03 to 0.08 & & \\
\hline Arm circumference $(\mathrm{cm})$ & $0 \cdot 19$ & 0.11 to 0.27 & & \\
\hline $\begin{array}{l}\text { Arm muscle } \\
\text { circumference }(\mathrm{cm})\end{array}$ & 0.18 & 0.07 to 0.30 & & \\
\hline $\begin{array}{l}\text { Subscapular skinfold } \\
\text { thickness }(\mathrm{mm})\end{array}$ & 0.08 & 0.05 to 0.12 & & \\
\hline $\begin{array}{l}\text { Triceps skinfold } \\
\text { thickness }(\mathbf{m m})\end{array}$ & $0 \cdot 10$ & 0.06 to 0.14 & & \\
\hline Systolic blood pressure & & & & \\
\hline$(\mathrm{mm} \mathrm{Hg})$ & 0.03 & 0.02 to 0.05 & & \\
\hline $\begin{array}{l}\text { Diastolic blood pressure } \\
(\mathrm{mm} \mathrm{Hg})\end{array}$ & 0.05 & 0.03 to 0.07 & & \\
\hline $\begin{array}{l}\text { Cholesterol }(\mathrm{mmol} / \mathrm{l}) \\
\text { Triglycerides }(\mathrm{mmol} / \mathrm{l})\end{array}$ & $\begin{array}{l}0.48 \\
0.45\end{array}$ & $\begin{array}{l}0.18 \text { to } 0.77 \\
0.19 \text { to } 0.70\end{array}$ & 0.49 & 0.13 to 0.85 \\
\hline $\begin{array}{l}\text { Serum uric acid (mmol/l) } \\
\text { Alcohol consumption }\end{array}$ & $\begin{array}{r}13.61 \\
1.07\end{array}$ & $\begin{array}{l}9.33 \text { to } 17.89 \\
0.33 \text { to } 1.80\end{array}$ & $\begin{array}{r}13.91 \\
1.21\end{array}$ & $\begin{array}{l}9.44 \text { to } 18.39 \\
0.33 \text { to } 2.09\end{array}$ \\
\hline
\end{tabular}

* Subjects not developing gout, $n=859$; subjects developing gout, $n=37$. Seventeen subjects were not included in the analysis because of incomplete data. 
considered, apart from age and height, were positively associated with the incidence of gout so that an increase in each risk factor contributed directly or indirectly to an increase in risk. For example, in the univariate logistic regression model when the serum uric acid concentration was used, the relative risk of gout for an increase from 0.36 to $0.48 \mathrm{mmol} / 1$ was $5 \cdot 12(95 \%$ confidence interval 3.06 to 8.56 ). This particular logistic regression analysis contained a bias due to the laboratory bias in serum uric acid estimations for those 231 people whose round I data came from the 1971 survey. Analyses excluding these people, however, as well as analyses using only round II and round III data, suggested that the extent of the bias in the estimated relation between the incidence of gout and serum uric acid concentration was negligible.

Forward stepwise multivariate logistic regression analysis showed that the best set of entry predictors of gout were age, serum uric acid concentration, alcohol use, and serum cholesterol concentration. This model accounted for $20.4 \%$ of the total variance. The relative risk of developing clinical gout for an increase in serum uric acid concentration from 0.36 to $0.48 \mathrm{mmol} / \mathrm{l}$ was 5.31 (confidence interval 3.01 to 9.08 ); for cholesterol the relative risk for an increase from 3.99 to $6.41 \mathrm{mmol} / \mathrm{l}$ was 3.25 (confidence interval 1.36 to $7 \cdot 78$ ); and for self reported current alcohol users the relative risk was $3 \cdot 35$ (confidence interval $1 \cdot 40$ to $8 \cdot 04$ ). A model including the body mass index instead of cholesterol concentration accounted for almost as much of the variance $(20.3 \%)$ and might be preferred by clinicians as body mass is easier to measure and is non-invasive. In this model the relative risk of having clinical gout was 1.70 (confidence interval 1.13 to 2.58 ) for an increase of 0.5 in the body mass index. Cox's proportional hazards regression was also used because it was a potentially more powerful tool for analysing these data. ${ }^{23}$ Because of the imprecision in ascertaining the onset of gout, however, the results of this analysis were closely comparable with those from the logistic analysis and yielded similar values for the various relative risks.

\section{Discussion}

Over the 14 years of this study the prevalence of gout in Tokelau showed a minor, but not significant, decrease from $19 \cdot 5 / 1000$ subjects in round I to $14 \cdot 6 / 1000$ in round III. In the first survey round in New Zealand the prevalence of gout was only marginally higher in migrant men $(21.0 / 1000)$ compared with non-migrant men $(19 \cdot 5 / 1000)$. An increase became apparent at the second round, when the prevalence in the migrant men reached $35 \cdot 0 / 1000$; it increased to $51.0 / 1000$ in the third round. As both non-migrants and migrants are of the same genetic admixture these changes highlight the important response to environmental changes that occur in migrants at risk for gout.

Among the Tokelauan men in New Zealand the high overall incidence of gout $(90 \cdot 7 / 10000$ person years at risk) places them in the same high risk class as New Zealand Maoris. ${ }^{6}$ In Tokelau the incidence was much lower at $11 \cdot 2 / 10000$ person years at risk. Age specific incidences showed that gout was occurring earlier in migrant men than non-migrant men. In the migrant men the largest number of new cases occurred among those aged 35-44, whereas in the non-migrant men it occurred among those aged 45-54. This pattern was evident in the prevalence data. Gout was fairly uncommon in women in both environments.

These results are most unlikely to be the result of bias, as although there were several possible sources of bias, its magnitude was thought to be small. Measurable follow up bias was unlikely with the high coverage rates in this study; also unlikely was misclassification of the presence or absence of gout. Many Tokelauans, both migrants and non-migrants, were known to have travelled back and forth between Tokelau and New Zealand. This is unlikely to have caused more than a small bias in attributing overall person years at risk to the two environments, particularly as people were excluded from the incidence study at the first examination after their return to Tokelau.

Expanded uric acid pools associated with the deposition of uric acid in and around joints is linked to the clinical occurrence of gout. ${ }^{25}$ The serum uric acid concentrations in both round II and round III were significantly higher in the migrants under 55 than in the non-migrants, which could be in response to a strong environmental effect. Concentrations in the older migrants were lower than those in the non-migrants. The difference in the incidence of gout between Tokelau and New Zealand may be related to several factors influencing purine metabolism associated with a build up of the total uric acid pool. The higher meat consumption in the migrants, the purine content of beer, the influence of alcohol on renal uric acid clearance, and the effect of a gain in body weight and increased muscle mass could all be contributing factors to the putative expanded uric acid pools in the migrants.

In the multivariate analysis age, serum uric acid and cholesterol concentrations, and self reported consumption of alcohol, all measured at entry, were significantly associated with the incidence of gout, and they may be regarded as the best predictive risk factors for gout. The mean body mass at entry was greater among those people who later developed gout than among those who remained gout free and was also a predictor of the incidence of gout in an alternative multivariate model. It should be noted that the subjects were already somewhat overweight before migration and that, overall, weights increased to a greater degree in the migrants than the non-migrants. Upper arm muscle circumference was shown to be a predictor of gout in the New Zealand Maori study ${ }^{6}$ as well as in our population.

Earlier work showed a relation between alcohol intake and serum uric acid concentration in Polynesians. ${ }^{4}$ The pattern of alcohol use is changing in Tokelauans both in New Zealand and in Tokelau; this represents changing attitudes to its use in both places. ${ }^{26}$ The age standardised prevalence of self reported current alcohol use in rounds I and III was $63 \%$ and $73 \%$ for migrant men in New Zealand and $36 \%$ and $62 \%$ for non-migrant men in Tokelau, respectively. Alcohol usage is greater in New Zealand than Tokelau.

Information concerning the mechanisms for the development of gout is not directly available from this study of Tokelauans. Recent work on a sample of 115 Maori men in New Zealand showed a lower urate clearance in gouty and hyperuricaemic subjects. ${ }^{5}$ This suggested that the susceptibility to hyperuricaemia had a renal mechanism in Maoris. Further studies are needed to elucidate these mechanisms in Tokelauan and other Pacific Islanders.

This study showed that the Tokelauan population has high serum uric acid concentrations, which are higher in younger migrants than non-migrants. The risk of gout was increased in the migrants, with a notably higher prevalence and incidence associated with urbanisation and a move to a more Western diet and lifestyle. An important genetic predisposition to gout may be present that is enhanced by the effects of migration. Prevention of weight gain through moderate dietary changes, prudent use of alcohol, and increased physical activity will help prevent gout in migrant Tokelauans. Patients with the disease should be supervised to achieve compliance with treatment regimens. These measures should also help to prevent associated disorders such as hypertension and diabetes.

We gratefully acknowledge the support of the Medical Research Council of New Zealand, the Wellington Hospital Board, the cardiovascular division of the World Health Organisation, and the cooperation of the Tokelau communities in Tokelau and New Zealand.

\section{References}

1 Prior IAM, Rose BS, Davidson F. Metabolic maladies in New Zealand Maoris. Br Med $\mathcal{J}$ 1964;i:1065-9.

Prior IAM, Rose BS, Harvey HPB, Davidson F. Hyperuricaemia, gout and diabetic abnormality in Polynesian people. Lancet 1966;i:333-8.

3 Rose BS. Gout in the Maoris. Semin Arthritis Rheum 1975;5:121-45.

4 Prior IAM. Epidemiology of rheumatic disorders in the south Pacific with emphasis on hyperuricaemia and gout. Semin Arthritis Rherum 1981;11:213-29.

5 Gyperuricaemia and gout. Semin Arthritis Rheum 1981;11:213-29. function in New Zealand Maori men. Br $\mathcal{F}$ Rhermatol 1984;23:276-82. Brauer GH, Prior IAM. A prospective survey of gout in New Zealand Maoris. Ann Rheum Dis 1978;37:466-72.

Jackson L, Taylor R, Faaiuso S, Ainuu SP, Whitehouse S, Zimmett P. Hyperuricaemia and gout in Western Samoans. 7 Chronic Dis 1981;34:65-76.

8 Zimmett PZ, Whitehouse S. Pacific Islands of Nauru, Tuvalu and Western Samoa. In: Trowel HC, Burkitt DP, eds. Western diseases: their emergence and prevention. London: Edward Arnold 1981:204-24.

9 Zimmett PZ, Whitehouse S, Jackson L, Thoma $\mathrm{K}$. High prevalence of hyperuricaemia and gout in an urbanised Micronesian population. Br Med f 1978 ;i:1237-9.

10 Healy LA, Caner JEZ, Bassett DR, Decker JL. Serum uric acid and obesity in Hawaiians. JAMA 1966;196:152-3.

11 Akizuki S. A population study of hyperuricaemia and gout in Japan-analysis of sex, age and occupation differences in thirty-four thousand people living in Nagano prefecture. Ryumachi 1982:22:201-8.

12 Ward RH, Raspe PD, Ramirez ME, Kirk RL, Prior IAM. Genetic structure and epidemiology: the Tokelau Island migrant study. In: Eriksson AW, Forsius A, Nevalinna H, eds. Population genetic studies on isolates. London: Academic Press, 1979:301-25. 
13 Prior IAM, Stanhope JM, Evans JG, Salmond CE. The Tokelau Island migrant study. Int $\mathcal{f}$ Epidemiol 1974;3:225-32.

14 Prior IAM, Hooper A, Huntsman JW, Stanhope JM, Salmond CE. The Tokelau Island migrant study. In: Harrison GE, ed. Population structure and human variation. Cambridge, Massachusetts: Cambridge University Press, 1977:165-86.

15 Prior IAM, Davidson F, Salmond CE, Czochanska Z. Cholesterol, coconuts and diet on Polynesian atolls: a natural experiment: the Pukapuka and Tokelau Island studies. $\mathrm{Am} \mathcal{J} \mathrm{Clin}$ Nutr 1981;34:1552-61.

16 Harding WR, Russell CE, Davidson F, Prior IAM. Dietary surveys from the Tokelau Island migrant study. Ecology of Food and Nutrition 1986;19:83-97.

17 Bennett PH, Burch TA. New York symposium on population studies in the rheumatic diseases: new diagnostic criteria. Bull Rheum Dis 1967;17:453-8.

18 Mantel N. Chi-square tests with one degree of freedom: extensions of the Mantel-Haenszel procedure. Foumal of the American Statistical Association 1963;58:690-700.
19 Armitage P'. Statistical methods in medical research. London: Blackwell, 1971.

20 Rothman KJ, Boice JD. Epidemiological analysis with a programmable calculator. Washington National Institutes of Health, 1979.

21 Crowley LV, Alton FL. Automated analysis of uric acid. Am f Clin Pathol 1968;49:285-8.

22 Stanhope JM, Sampson VM, Prior IAM. The Tokelau Island migrant study: serum lipid concentrations in two environments. F Chronic Dis 1981;34:45-55.

23 SAS Institute. SAS supplementary user's guide. Raleigh, North Carolina: SAS Institute, 1982

24 SAS Institute. SAS user's guide. Raleigh, North Carolina: SAS Institute, 1981.

25 Boss GR, Seegmillar JE. Hyperuricemia and gout. N Engl f Med 1979;300:1459-68.

26 Stanhope JM, Prior IAM. The Tokelau Island migrant study: alcohol consumption in the two environments. NZ Med I 1979;90:419-21.

\title{
Extreme cutaneous histamine sensitivity with hay fever and increased IgE concentrations in an unselected population
}

\author{
CAMPBELL S WITT, MARTIN S STUCKEY, ROGER L DAWKINS
}

\begin{abstract}
Cutaneous sensitivity to histamine, responses to prick tests with allergens, and serum IgE concentrations were measured and hay fever assessed by questionnaire in an unselected population to determine whether increased sensitivity to histamine is an independent phenomenon contributing to allergic disorders or may be caused by allergic reactions. Increased cutaneous sensitivity to histamine was strongly associated with an increased number of positive responses to prick tests, high serum concentrations of IgE, and hay fever. This new test is simple, cheap, applicable to schoolchildren, and provides useful information.
\end{abstract}

\section{Introduction}

Subjects suffering from hay fever have an increased sensitivity of the nasal mucosa to histamine ${ }^{1}$ and positive responses to allergens on cutaneous prick testing. ${ }^{2}$ It is not known whether this increased sensitivity to histamine is restricted to nasal mucosa or whether skin is also affected. Furthermore, it is not known whether increased sensitivity to histamine and positive responses to prick test allergens are distributed independently in the population, with hay fever representing the coincidence of both traits, or are associated.

We and others have reported that there is a range of cutaneous histamine sensitivity in the population. ${ }^{34}$ In this study we measured cutaneous sensitivity to histamine, allergen prick test responses, and serum IgE concentrations and assessed hay fever in an unselected population.

\footnotetext{
Department of Clinical Immunology, Queen Elizabeth II Medical Centre, Nedlands, Western Australia

CAMPBELL S WITT, PHD, senior research officer

ROGER L DAWKINS, FRCPA, FRACP, associate professor and head

State Health Laboratory Services of Western Australia

MARTIN S STUCKEY, FRACP, FRCPA, immunologist
}

Correspondence to: Associate Professor R L Dawkins, Department of Clinical Immunology, Royal Perth Hospital, GPO Box X2213, Perth, Western Australia 6001 .

\section{Subjects and methods}

Study population-The adults studied consisted of 3953 out of a total of roughly 7000 adults in the Busselton electorate who were asked to participate in the 1981 Busselton health survey. Their ages ranged from 18 to 88 (mean 49.6). Five consecutive adults out of each 15 attending for the survey (that is, 889 of 2670) were skin tested. All primary schools in the Busselton electoral area and one of the two high schools were surveyed in 1983 . Over $95 \%$ of children attending school on the day of the visit completed a questionnaire. The children's ages ranged from 6 to 19 (mean 11.5). A total of 1307 children were skin tested. The first 400 were selected by testing every second child surveyed while the 907 others were selected by testing every child surveyed.

Measurement of histamine sensitivity-Each subject was prick tested by the method of Pepys ${ }^{5}$ with four dilutions of histamine phosphate dissolved in phosphate buffered saline and a control solution of the saline alone. Two diameters of any weals that resulted were recorded 15 minutes after application of the solution and the mean diameter recorded. The lowest concentration of histamine that produced a weal diameter of at least $2 \mathrm{~mm}$ was designated the histamine threshold concentration for that subject. The concentrations of histamine used were $1 \cdot 0,0 \cdot 1,0 \cdot 01$, and $0.001 \mathrm{mg} / \mathrm{ml}$. Subjects not responding to $1.0 \mathrm{mg} / \mathrm{ml}$ were said to have a histamine threshold concentration of $10 \mathrm{mg} / \mathrm{ml}$. Correction for responses to the control saline was not attempted; $83(9 \cdot 2 \%)$ adults and $14(1 \cdot 1 \%)$ children responded to the control saline.

Allergen prick testing-All subjects were prick tested by the method of Pepys $^{5}$ with 14 allergens-namely, six local grass pollens, two weeds, one tree pollen, cattle, cat, and dog danders, and extracts of aspergillus and Dermatophagoides farinae in $50 \%$ glycerinated saline (Holister-Stier Laboratories, Spokane, Washington, United States). ${ }^{3}$ Allergen groups were defined on the basis of strong cross reactivity. Thus a positive response to any one of five grass extracts (in adults) or six grass extracts (in children) was considered a positive reaction to the grass group. Two weed and two house dust mite extracts were treated similarly. This resulted in eight different allergen groups for adults and seven for children. Weals with an average diameter of at least $2 \mathrm{~mm}$ were counted as a positive response.

Measurement of IgE concentration-Total serum IgE concentrations were measured in a subset of 400 adults by PRIST (Pharmacia Diagnostics, Uppsala, Sweden). Subjects were selected for one of three reasons. (1) They had previously given a positive result on bee venom radioallergosorbent testing $(n=110)$. (2) They had been previously HLA typed (selection for typing was random $)(n=220)$. (3) They were part of a family study on IgE (families were not selected for allergic symptoms or high IgE concentration) $(\mathbf{n}=70)$.

Definition of hay fever-The diagnosis of allergic rhinitis and hay fever was made by questionnaire. Subjects were asked to answer the following questions with a yes or no. Have you ever had longlasting or frequent: $(a)$ blockage of the nose, nasal stuffiness? $(b)$ watery discharge from the nose? and $(c)$ sneezing or itching of the nose, roof of mouth, or throat? $(d)$ are the symptoms still present? They were also asked to circle the month(s) of the year when the symptoms in questions $(a),(b)$, and $(c)$ were present and when 